\title{
Screening, Characterization and Biofilm Formation of Nickel Resistant Bacteria Isolated from Indigenous Environment
}

\author{
HAFIZ Z. WADOOD ${ }^{1 *}$ and ANJUM N. SABRI ${ }^{1}$ \\ ${ }^{1}$ Department of Microbiology and Molecular Genetics, Faculty of Life Sciences \\ University of the Punjab, Lahore, Pakistan
}

Submitted 22 February 2013, revised 5 July 2013, accepted 16 November 2013

\begin{abstract}
Nickel resistant bacteria (ZB, ZC, ZD, ZL, ZK and S1X) were isolated from industrial effluents and corroded iron pieces from indigenous environment of Punjab, Pakistan. These six strains could tolerate nickel at different levels with ZB, ZC, ZD, ZL, ZK, and SIX having 233 , $225,267,233,228$ and $296 \mathrm{mM}$ minimum inhibitory concentration (MIC) of nickel ions, respectively. These bacteria were sensitive to $\mathrm{Cu}^{+2}$, $\mathrm{Cr}^{+3}, \mathrm{Co}^{+2}$, and $\mathrm{Al}^{+3}$ as they did not grow even in the presence of $1 \mathrm{mM}$ concentration of all these ions in minimal medium, whereas all of them were resistant to $\mathrm{Fe}^{+3}$ upto $1.3 \mathrm{mM}$ in minimal medium. The best appropriate temperature for nickel resistant bacteria was $37^{\circ} \mathrm{C}$ and all of them showed maximum growth at pH 8. These bacteria were characterized morphologically and biochemically. Biofilm forming ability of the bacteria was checked with and without nickel stress and it was found that strains ZK and S1X were able to form a compact biofilm even under nickel stress. The sequencing of $16 \mathrm{~S}$ rRNA-encoding genes from these nickel resistant bacteria showed that they belonged to four different genera namely, Klebsiella, Pseudomonas, Bacillus and Cronobacter.
\end{abstract}

Ke y word s: Nickel resistant bacteria, minimal medium, minimum inhibitory concentration (MIC), biofilm

\section{Introduction}

During last few decades, increased industrialization has resulted in environmental contamination with various pollutants, among those heavy metals are of serious concern because food chains can accumulate these heavy metals, causing serious hazards to the environment (Chen et al., 2008; Durve etal., 2012; Wani and Khan, 2013). Nickel is being widely used in various industries such as leather tanning, electroplating, pulp processing, steel manufacturing and wood preservation and is discharged into wastewater and surrounding environment by these industries. This is of key concern because of non-degradable nature of nickel (Congeevaram et al., 2007; Karakagh et al., 2012). Nickel is typically found in $\mathrm{Ni}(0)$ or $\mathrm{Ni}$ (II) state due to the stability of these species in water (Nieminen et al., 2007). Nickel is an essential compound for bacterial metabolism (Hausinger, 1987) and is used as a co- factor by several well characterized microbial enzymes like urease, hydrogenase, Ni-superoxide dismutase, carbon monoxide dehydrogenase, acetyl CoA synthase/decarbonylase, and methyl coenzyme $\mathrm{M}$ reductase, as well as some forms of glyoxalase (Mulrooney and Hausinger, 2006; Ragsdale, 2009; Kaluarachchi et al.,2010; Li and Zamble,
2010), but at higher concentrations nickel becomes toxic (Nies, 1992). The bacterial strain which can resist Ni (II) concentration greater than $99.8 \mathrm{mg} / \mathrm{l}$ may be considered as nickel resistant bacterial strain (Duxbury, 1981). Bacterial resistance to nickel is dependent upon a specific efflux system which is an operon-encoded and energydependent system that pumps excess of $\mathrm{Ni}^{2+}$ out of the cell and thus lowers the intracellular $\mathrm{Ni}^{2+}$ concentration (Park et al., 2003; Mulrooney and Hausinger, 2006). The presence of nickel in the surrounding medium induces the expression of nickel resistant determinant in bacterial strains (Zhu et al., 2011).

Interestingly, biofilm formation in many bacterial species is motivated by some stresses such as elevated metal concentration or some non-optimal growth conditions in the immediate environment of bacterial cells (Castonguay et al., 2006; Harrison et al., 2007). A biofilm is an aggregation of microbial cells which can be established on different surfaces. Biofilm is encapsulated by a self-produced matrix of extracellular polymeric substances (EPS), which is mainly composed of polysaccharides, proteins, nucleic acids, and lipids (Flemming and Wingender, 2010; Abee et al., 2011). Studies have shown that bacterial cells in biofilms are more resistant to the detrimental effects of heavy

\footnotetext{
* Corresponding author: H.Z. Wadood, phone: +92-423-5952811; e-mail: shan_wadood@yahoo.com
} 
metals than planktonic cells as they show better survival than free floating bacteria in the metal contaminated environment (Booth et al., 2011; Ansari et al., 2012). The present study was aimed at the isolation, characterization and identification of nickel resistant bacteria, to find out minimum inhibitory concentration (MIC) of nickel metal and to check the biofilm formation of these isolated bacteria under nickel stress.

\section{Experimental}

\section{Materials and Methods}

Sample Collection. Wastewater samples (from KotLakhpat Industrial Estate Lahore, Pakistan) and corroded iron pieces (from old iron market Lahore, Pakistan) were collected in screw capped sterilized bottles and plastic bags respectively. Some physicochemical parameters like $\mathrm{pH}$ and temperature of wastewater were measured at the site of collection.

Isolation of Nickel Resistant Bacteria. For the isolation of nickel resistant bacteria, $50 \mu$ l of wastewater and $50 \mathrm{mg}$ of scratched corrosion product from corroded iron pieces were separately spread and sprinkled on nutrient agar (Cappuccino and Sherman, 2007) plates supplemented with $1 \mathrm{mM}$ of nickel chloride $\left(\mathrm{NiCl}_{2} \cdot 6 \mathrm{H}_{2} \mathrm{O}\right)$. The plates were incubated at $37^{\circ} \mathrm{C}$ for 24 hours. The bacterial colonies were selected and purified on nickel chloride $(1 \mathrm{mM})$ supplemented nutrient agar plates. After purification, the selected bacteria were shifted to slightly modified minimal agar medium as described by Schmidt et al., 2007. Bacterial growth was checked with $(1 \mathrm{mM})$ and without nickel metal. The modified minimal agar medium contained $1 \mathrm{~g}\left(\mathrm{NH}_{4}\right)_{2} \mathrm{SO}_{4}, 0.5 \mathrm{~g} \mathrm{~K}_{2} \mathrm{HPO}_{4}, 0.2 \mathrm{~g} \mathrm{MgSO}_{4} \cdot 7 \mathrm{H}_{2} \mathrm{O}$, $0.01 \mathrm{~g} \mathrm{FeSO}_{4} \cdot 7 \mathrm{H}_{2} \mathrm{O}, 10 \mathrm{~g}$ glucose, $15 \mathrm{~g}$ agar and $11 \mathrm{dis}-$ tilled water. The plates were again incubated at $37^{\circ} \mathrm{C}$ for 24 hours.

Characterization of nickel resistant bacteria. Nickel resistant bacterial isolates were characterized morphologically and biochemically (Cappuccino and Sherman, 2007). Two parameters i.e., $\mathrm{pH}$ and temperature were selected to check optimum growth of bacterial isolates. For the determination of optimum temperature, three sets of test tubes with minimal broth medium were prepared and inoculated with overnight culture of each bacterium. The three sets were incubated overnight at 28,37 , and $45^{\circ} \mathrm{C}$ respectively and absorbance of cultures was measured at $600 \mathrm{~nm}$ using IRMECO uv-vis spectrophotometer. For the determination of optimum $\mathrm{pH}$, four sets of test tubes with minimal broth medium were prepared and their $\mathrm{pH}$ was adjusted at 5, 6, 7, and 8 then autoclaved. These tubes were then inoculated with overnight culture of each strain. After overnight incubation, absorbance of cultures was measured at $600 \mathrm{~nm}$ using IRMECO uv-vis spectrophotometer.
Determination of minimum inhibitory concentration (MIC) of nickel for the bacterial isolates. Minimum inhibitory concentration (MIC) against nickel was determined by broth dilution method. Stock solution $(1.26 \mathrm{M})$ of $\mathrm{NiCl}_{2} \cdot 6 \mathrm{H}_{2} \mathrm{O}$ was prepared in sterile distilled water. Sterile minimal broth medium with varying concentrations $(0 \mathrm{mM}$ to $300 \mathrm{mM})$ of nickel metal was prepared in test tubes ( $5 \mathrm{ml}$ broth per tube). Overnight bacterial cultures were then diluted to reach a final optical density of 0.3 at $600 \mathrm{~nm}\left(\mathrm{OD}_{600}=0.3\right)$ for all the bacterial isolates, $50 \mu \mathrm{l}$ of bacterial inoculum per tube was added to each set of tubes designated for respective bacteria. Ion supplemented minimal broth medium was used as negative control for each concentration of nickel. These tubes were then incubated for 24 hours at $37^{\circ} \mathrm{C}$ at $100 \mathrm{rpm}$. The MIC was defined as the lowest concentration of nickel metal at which the bacteria do not show visible growth (Randrianarivelo et al., 2009). The experiment was performed twice in duplicates and MIC is presented as mean values of the experimental results.

Resistance to other heavy metal ions. The resistance of these isolated bacteria against other heavy metals was checked in minimal agar medium. The other heavy metals used were as follows: $\mathrm{Al}_{2}\left(\mathrm{SO}_{4}\right)_{3} \cdot 18 \mathrm{H}_{2} \mathrm{O}$, $\mathrm{CuSO}_{4} \cdot 5 \mathrm{H}_{2} \mathrm{O}, \mathrm{FeCl}_{3} \cdot 6 \mathrm{H}_{2} \mathrm{O}, \mathrm{CoCl}_{2} \cdot 6 \mathrm{H}_{2} 0$ and $\mathrm{K}_{2} \mathrm{CrO}_{4}$. The plates were incubated at $37^{\circ} \mathrm{C}$ and growth was observed till 48 hours.

Determination of biofilm formation of bacterial cells. A qualitative assay for biofilm formation of nickel resistant bacteria was performed in glass test tubes. Bacterial cultures were grown in minimal medium with and without nickel metal (170 mM) stress for 24 hours without agitation. After 24 hours, the liquid medium was removed, and the bacterial biofilm was visualized by following Qurashi and Sabri 2012.

Determination of effect of nickel metal (170 mM) on planktonic, loosely attached and tightly bound cells/biofilm growth. Biofilm formation of nickel resistant bacteria was quantified in terms of planktonic, loosely attached and tightly bound cells in borosilicate tubes with and without nickel added. Overnight bacterial cultures (in minimal broth medium) were standardized $\left(\mathrm{OD}_{600}=0.1\right)$ and $100 \mu \mathrm{l}$ standardized cultures were inoculated into $5 \mathrm{ml}$ of minimal broth medium. Tubes were incubated at $37^{\circ} \mathrm{C}$ for 72,120 , and 168 hours under static conditions. Two sets of tubes were used for each bacterial isolate, one set with nickel metal stress $(170 \mathrm{mM})$ and one set as control without nickel metal stress. After incubation, bacterial cultures were processed as previously described by Liaqat et al., 2009. The experiment was performed twice in duplicates.

Identification of bacterial isolates. To identify the taxonomic position, the isolated bacteria were sent to Macrogen Inc. Seoul South Korea for 16S rRNA gene sequencing. Obtained sequences were analyzed using 
Table I

Physicochemical characteristics of wastewater.

\begin{tabular}{|l|c|l|c|c|}
\hline $\begin{array}{c}\text { Sample } \\
\text { No. }\end{array}$ & $\begin{array}{c}\text { Sample } \\
\text { Type }\end{array}$ & \multicolumn{1}{|c|}{ Locality } & $\begin{array}{c}\text { pH of } \\
\text { samples }\end{array}$ & $\begin{array}{c}\text { Temperature } \\
\text { of samples }\end{array}$ \\
\hline S1 & Waste water & Main Drain Green town Lahore, Pakistan & 8 & $36^{\circ} \mathrm{C}$ \\
\hline S2 & Waste water & Central Drain KotLakhpat Industrial Estate, Lahore, Pakistan & 8 & $39^{\circ} \mathrm{C}$ \\
\hline S3 & Waste water & Drain outside of a factory, KotLakhpat Industrial Estate, Lahore, Pakistan & 8.5 & $37^{\circ} \mathrm{C}$ \\
\hline
\end{tabular}

Table II

Morphological and biochemical characteristics of nickel resistant bacteria.

\begin{tabular}{|c|c|c|c|c|c|c|}
\hline \multirow{2}{*}{ Characteristics } & \multicolumn{6}{|c|}{ Bacterial Isolates } \\
\hline & $\mathrm{ZB}$ & $\mathrm{ZC}$ & $\mathrm{ZD}$ & $\mathrm{ZL}$ & $\mathrm{ZK}$ & $\mathrm{ZB}$ \\
\hline Colony shape & Circular & Circular & Circular & Circular & Circular & Irregular \\
\hline Colony elevation & Convex & Convex & raised & Raised & Flat & Flat \\
\hline Colony Color & Off white & Off white & Yellow & Off white & Green & Off white \\
\hline Colony size $(\mathrm{mm})$ & $1-1.5$ & 2 & 1 & $0.5-1$ & $2-2.5$ & $2-3$ \\
\hline Colony margin & Entire & Entire & Entire & Entire & Entire & Undulate \\
\hline Cell shape & Bacilli & Bacilli & Bacilli & Bacilli & Bacilli & Bacilli \\
\hline Gram staining & - & - & - & - & - & + \\
\hline Catalase & + & + & + & + & + & + \\
\hline Cytochrome oxidase & - & - & - & - & + & - \\
\hline Urease test & - & - & - & - & - & - \\
\hline Oxidation fermentation & F.A & F.A & F.A & F.A & $\bar{A}$ & F.A \\
\hline Methyl red & - & - & - & - & - & - \\
\hline Voges Proskauer & - & - & - & - & - & + \\
\hline Starch hydrolysis & - & - & - & - & - & + \\
\hline Gelatin Hydrolysis & - & - & S.H & - & R.H & R.H \\
\hline Hydrogen Sulfide test & - & - & - & - & - & - \\
\hline
\end{tabular}

F.A = Facultative Anaerobes, $\mathrm{A}=$ Aerobes, $\mathrm{S} . \mathrm{H}=$ Slow Hydrolysis and $\mathrm{R} . \mathrm{H}=$ Rapid hydrolysis

Finch TV (Geospiza, Inc. Seattle, WA) software and compared with the known sequences in the GenBank database through the National Center for Biotechnology Information (NCBI) to identify the most similar sequence alignment. These sequences of nickel resistant bacteria were then deposited in GenBank in order to get the accession numbers.

Statistical analysis. The results obtained in the quantification of biofilm in terms of planktonic, loosely attached and tightly bound cells were statistically analyzed using two-way ANOVA.

\section{Results}

\section{Physicochemical characteristics of wastewater}

The $\mathrm{pH}$ of different wastewater samples ranged from 8 to 8.5 and temperature ranged from 36 to $39^{\circ} \mathrm{C}$ (Table I).

\section{Nickel resistant bacteria}

A total of 26 bacterial isolates were selected from different samples on nickel chloride supplemented
(1 mM) nutrient agar plates. Fourteen strains were selected from plates spread with wastewater samples and 12 strains were selected from plates sprinkled with corrosion products from corroded iron pieces. These 26 bacterial isolates were purified and seeded into the elevated level of nickel metal in minimal medium. Total of 6 bacterial isolates (ZB, ZC, ZD, ZL, ZK, and S1X) were selected based on their high resistance to nickel metal in minimal medium.

\section{Characterization of nickel resistant bacteria}

The six nickel resistant bacterial strains were characterized morphologically and biochemically. The results are depicted in Table II. The optimum temperature for growth of nickel resistant bacteria was found to be $37^{\circ} \mathrm{C}$ and all the bacterial isolates showed maximum growth at $\mathrm{pH} 8$ (Figure $1 \mathrm{~A}$ and $1 \mathrm{~B}$ ).

\section{Minimum Inhibitory Concentration (MIC) of nickel metal for the selected bacterial isolates}

Minimum inhibitory concentration (MIC) of nickel ions for these selected bacterial isolates was determined 


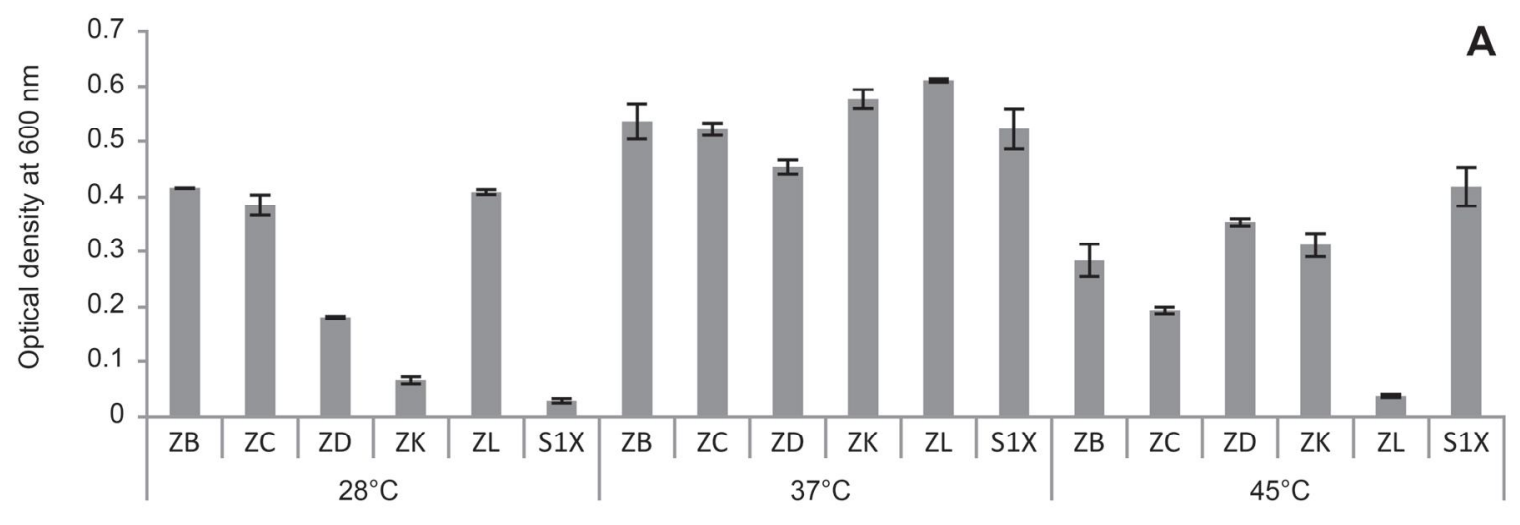

Bacterial isolates and temperature

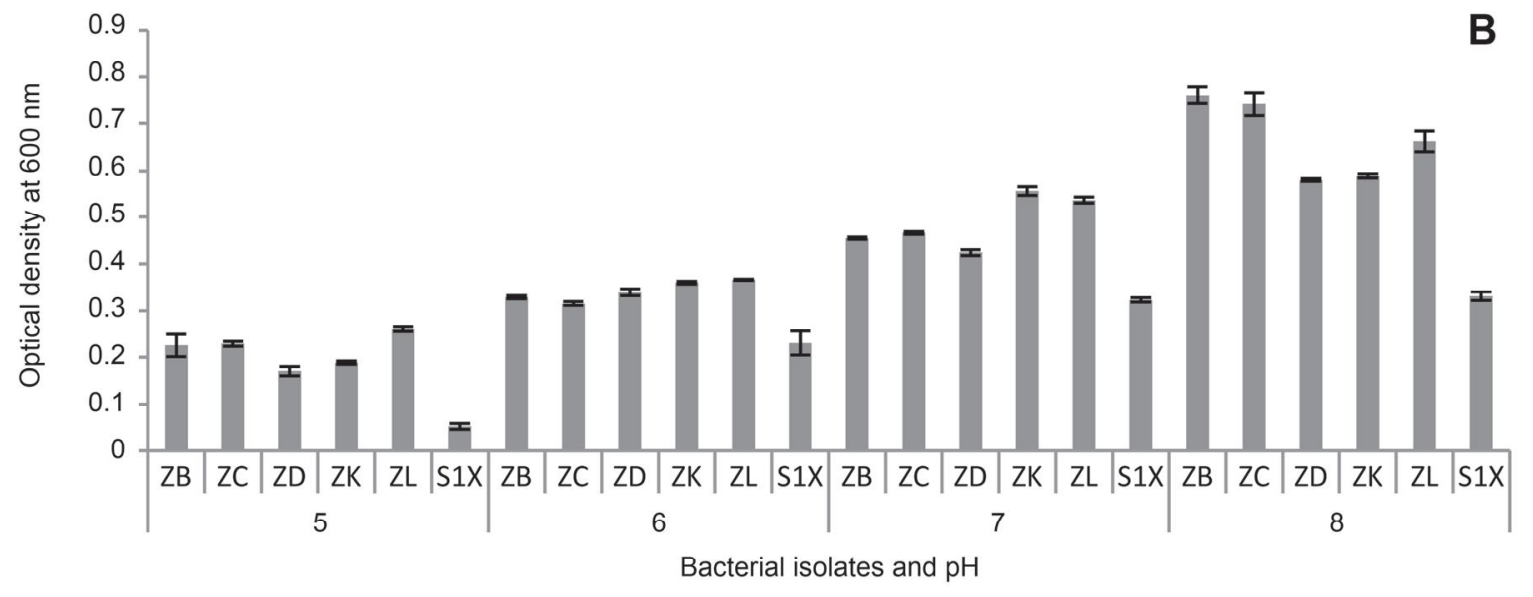

Fig. 1. Effect of Temperature (A) and pI (B) on bacterial growth.

by broth dilution method and MIC values ranged from $225 \mathrm{mM}$ to $296 \mathrm{mM}$. The bacterial strains $\mathrm{ZB}, \mathrm{ZC}, \mathrm{ZD}$, $\mathrm{ZL}, \mathrm{ZK}$, and S1X showed minimum inhibitory concentration (MIC) of nickel 1 at 233, 225, 267, 233, 228 and $296 \mathrm{mM}$ respectively.

\section{Resistance to other heavy metal ions}

These bacterial isolates (ZB, ZC, ZD, ZL, ZK, and $\mathrm{S} 1 \mathrm{X}$ ) were further tested for their resistance against various other heavy metals. All the isolates were sensitive to $\mathrm{Cu}^{+2}, \mathrm{Cr}^{+3}, \mathrm{Co}^{+2}$, and $\mathrm{Al}^{+3}$ as these bacteria did not show growth even at $1 \mathrm{mM}$ concentration of all these metals in minimal medium, whereas all of these bacterial isolates were resistant to $\mathrm{Fe}^{+3}$ upto $1.3 \mathrm{mM}$.

\section{Biofilm formation of bacterial cells}

Biofilm formed by the nickel resistant bacteria (ZB, $\mathrm{ZC}, \mathrm{ZD}, \mathrm{ZL}, \mathrm{ZK}$ and $\mathrm{S} 1 \mathrm{X}$ ) was visualized as dark purple ring formed on the walls and base of the test tubes in a qualitative analysis.

\section{Effect of nickel metal $(170 \mathrm{mM})$ on planktonic, loosely attached and tightly bound cells/biofilm growth}

The effect of nickel $(170 \mathrm{mM})$ on the planktonic, loosely attached, and tightly bound cells of bacteria was studied. Strains ZB, ZC, ZK and S1X showed a decrease in planktonic and loosely attached cells under nickel stress as compared to control. An increase in tightly bound cells was observed for strains ZB, ZK and S1X from 72 to 168 hours in both control and Ni stressed medium. In case of strain $\mathrm{ZC}$, an increase in amount of tightly bound cells was observed by 168 hours in control and by 120 hours under nickel stress. In strains $\mathrm{ZD}$ and $\mathrm{ZL}$ a decrease in numer of planktonic cells was observed by 168 hours under Ni stress whereas number of loosely attached and tightly bound cells increased by 168 hours for ZD under nickel stress. In case of ZL, number of loosely attached cells increased under $\mathrm{Ni}$ stress whereas number of tightly bound cells/biofilm was the same in both control and under Ni stress (Figure $2 \Lambda-F$ )

\section{Identification of bacterial isolates}

The 16S rRNA gene sequencing revealed that $\mathrm{ZB}$, ZC and ZL isolates showed sequence similarity (99\%) to Klebsiella pneumoniae strain DSM 30104. ZD was 99\% similar to Cronobacter sakazakii strain ATCC 29544. Whereas ZK and S1X showed sequence similarity (99\%) to Pseudomonas aeruginosa strain DSM 50071 and Bacillus subtilis subsp. subtilis strain DSM 10 respectively. The nucleotide sequences coding for $16 \mathrm{~S}$ rRNA genes of nickel resistant bacteria have been 

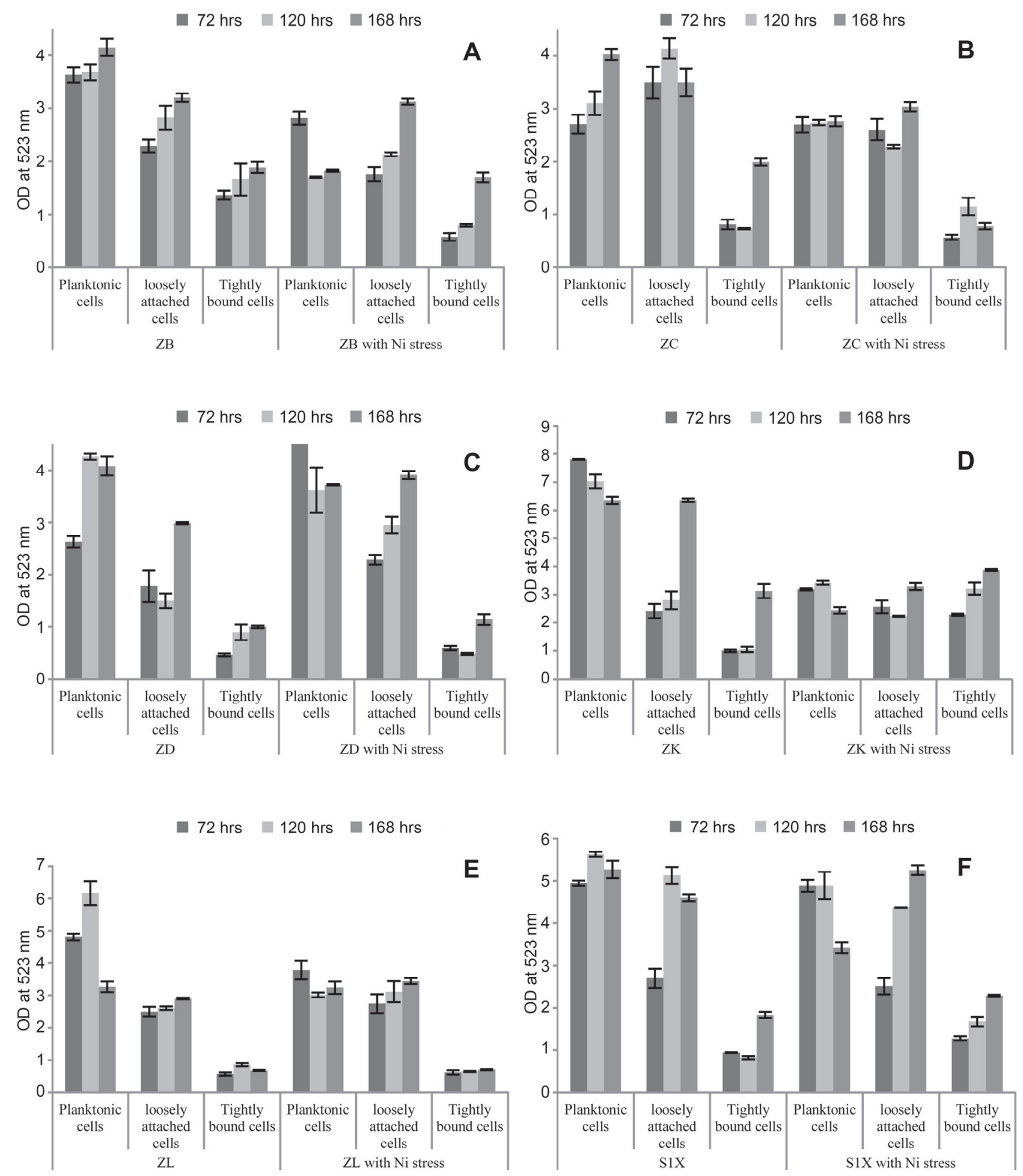

Fig. 2. Effect of Nickel metal ( $170 \mathrm{mM}$ ) on planktonic, loosely attached and tightly bound cells/biofilm growth of Klebsiella pneumoniae strain ZB (A), Klebsiella pneumoniae strain ZC (B), Cronobacter sakazakii strain ZD (C), Pseudomonas aeruginosa strain ZK (D), Klebsiella pneumoniae strain ZL (E) and Bacillus subtilis strain S1X (F) in borosilicate test tubes.

submitted to NCBI GenBank database under accession numbers Bacillus subtilis strain S1X (KC243314), Klebsiella pneumoniae strain ZB (KC243315), Klebsiella pneumoniae strain ZC (KC243316), Cronobacter sakazakii strain ZD (KC243317), Pseudomonas aeruginosa strain ZK (KC243318) and Klebsiella pneumoniae strain ZL (KC243319).

\section{Statistical analysis}

Difference in planktonic, loosely attached and tightly bound cells, both in control and $\mathrm{Ni}$ stressed conditions at different incubation times, was analyzed using two-way ANOVA. Significant difference was observed $(\mathrm{P}<0.05)$ in all three types of cells for all the bacterial strains (ZB, ZC, ZD, ZL, ZK and S1X) with 
a few exceptions. Number of loosely attached cells for $\mathrm{ZC}$ and planktonic cells for ZD were not significantly different $(\mathrm{P}>0.05)$ with respect to incubation times. For ZD and ZL significant difference was not found for tightly bound cells under control and stressed conditions $(P>0.05)$. In case of S1X, loosely attached cells were also not significantly different under control and $\mathrm{Ni}$ stress conditions $(\mathrm{P}>0.05)$.

\section{Discussion}

The existence of heavy metals in the surroundings of microbes can affect their growth, morphology and biochemical activities (Gadd, 1992; Roane and Pepper, 1999). Microbes have evolved different types of resistance and tolerance mechanisms for their survival in metal contaminated environment. These mechanisms may include (i) specific efflux pumps to expel toxic metal out of the cell, (ii) aggregation of the toxic metals, (iii) reduction in the permeability of microbial cell membranes, (iv) enzymatic modification of toxic metals to a less toxic form (Nies, 1999; Bruins et al., 2000; Nies, 2006). Nickel resistant bacteria have been isolated from different Ni polluted environments as wastewater, mine refuse, industrial composts (e.g. metallurgical and batteries industries) and cooling water from the metal processing industry (Park et al., 2003). In this study, a total of six bacterial strains have been isolated showing minimum inhibitory concentrations (MIC) for $\mathrm{Ni}^{+2}$ in the range of $225 \mathrm{mM}$ to $296 \mathrm{mM}$ with the highest MIC value for isolate S1X (Bacillus sp.) and lowest value for isolate ZC (Klebsiella sp.). These higher values of MIC of nickel for the isolated bacteria may be attributed to the presence of a plasmid encoded inducible energydependent efflux pump (Liesegang et al., 1993). It has been reported that these nickel efflux pumps are best characterized in organisms exhibiting hyper-resistance to nickel metal, although nickel efflux is widely used by cells to protect against elevated concentrations of this metal, several other mechanisms are also utilized by microorganisms to combat the elevated nickel concentration (Macomber and Hausinger, 2011). All of these bacteria showed resistance upto1.3 $\mathrm{mM}$ for $\mathrm{Fe}^{+3}$ and were found sensitive to other heavy metals like $\mathrm{Cu}^{+2}, \mathrm{Co}^{+2}, \mathrm{Al}^{+3}$, and $\mathrm{Cr}^{+3}$. Nickel resistance has been reported in species of different bacterial genera such as Streptomyces (Amoroso et al., 2000; Karakagh et al., 2012), Pseudomonas sp. and Bacillus sp. (Pal et al., 2004; Karakagh etal., 2012), Pseudomonas putida MH1d, Enterobacter intermedius MH8b, Enterobacter intermedius AM15, Klebsiella pneumoniae AM12 (Markowicz et al., 2010), Methylobacterium oryzae strain CBMB20, Burkholderia sp. Strain CBMB40 (Madhaiyan et al., 2007). Enterococcus sp. (De Niederhäusern et al., 2013),
Micrococcus sp. (Congeevaram et al., 2007). Geobacillus toebii subsp. decanicus and Geobacillus thermoleovorans subsp. stromboliensis (Özdemir et al., 2012). The survival of microbial cells under the influence of toxic compounds is a multifactorial phenomenon, which might be achieved by molecular mechanisms of resistance against these toxic compounds as well as by the development of biofilm on a substrate under stressed conditions (Harrison et al., 2007; Perrin et al., 2009). In this present study the effect of nickel $(170 \mathrm{mM})$ on the planktonic, loosely attached and tightly bound cells/biofilm has been studied for the bacterial strains $\mathrm{ZB}, \mathrm{ZC}, \mathrm{ZD}, \mathrm{ZL}, \mathrm{ZK}$, and SIX. Generally, a trend for decrease in planktonic and loosely attached cells has been observed under nickel stress compared to control which might be the result of some toxic effects of nickel ions on bacterial cells. These toxic effects might involve (1) replacement of some essential metal of metalloproteins by nickel, (2) binding of nickel to catalytic residues of non-metal enzymes, (3) binding of nickel outside the catalytic site of an enzyme to inhibit allosterically and (4) oxidative stress caused by nickel that can affect proteins, DNA, or lipids (Macomber and Hausinger, 2011). In case of tightly bound cells or biofilm formation on the glass test tubes, the results vary among different bacterial strains. For strain ZB (Klebsiella sp.), a decrease in tightly bound cells has been observed under Ni stress, but with respect to time of incubation an increase in tightly bound cells has been observed from 72 hours to 168 hours in control as well as under nickel stress (Fig. 2A). In case of strain ZC (Klebsiella sp.) an increase in tightly bound cells has been observed after 120 hours in control medium which may be due to the depletion of nutrients in the medium which forced the bacterial cells to develop biofilm for their survival under this stress, whereas under $\mathrm{Ni}$ stress a decrease in tightly bound cells is observed after 120 hours which means that after 120 hours biofilm either stabilizes or bacterial cells start shedding from the surface (Fig. 2B) (Liaqat et al., 2009). For ZD (Cronobacter sp.) strain, tightly bound cells increase from 72 to 168 hours under control medium whereas, under $\mathrm{Ni}$ stress increase in tightly bound cells/biofilm has been observed after 120 hours. These observations may be attributed to the fact that after a certain time, depletion of nutrients and presence of metal stressor in the medium force the bacterial cells to change from free floating cells to biofilm mode which protects the cells under stressed conditions (Fig. 2C). For ZL (Klebsiella sp.) strain, tightly bound cells/biofilm is same both under control and Ni supplemented medium at all the incubation times (Fig. 2E). For ZK (Pseudomonas sp.) and S1X (Bacillus sp.) strains, an increase in tightly bound cells/biofilm has been observed under nickel stress compared to control and this increase has also been observed from 72 to 
168 hours. Whereas in control medium biofilm formation has been found to be increasing after 120 hours which shows that bacterial cells have shifted from free floating form of life to biofilm mode for their survival under stressed conditions of nutrient deficiency and nickel concentration (Fig. 2D, 2F). It has been reported that sub inhibitory concentration of nickel metal urges Escherichia coli cells to develop biofilm for their survival under stress conditions, rather than living as planktonic cells (Perrin et al., 2009). So from this study it can be suggested that nickel stress may force bacterial cells to alter their lifestyle from free floating cells to biofilms, to resist the toxic effects of nickel metal.

Remediation of heavy metals using microbial species is a well documented and efficient process. In this study heavy metal resistance pattern bresented by studied bacteria was investigated and data show that bacteria were highly resistant to nickel and some of the strains show greater tendency to form biofilm as their survival strategy under this stressed condition. Biofilms are an appropriate source for the remediation of pollutants due to their high resistance and ability to immobilize the pollutants in the biofilm matrix. Hence, it can be suggested that these bacteria can be used as bioremediation tool for the treatment of industrial effluents.

\section{Acknowledgements}

Department of Microbiology and Molecular Genetics, University of the Punjab, Lahore, Pakistan and Higher Education Commission (HEC) Pakistan is greatly acknowledged for providing facilities and funds for support of this research work.

\section{Literature}

Abee T., Á.T. Kovács, O.P. Kuipers and S.Van der Veen. 2011. Biofilm formation and dispersal in Gram-positive bacteria. Curr. Opin. Biotech. 22: 172-179.

Amoroso M.J., D. Schubert, P. Mitscherlich, P. Schumann and E. Kothe. 2000. Evidence for high affinity nickel transporter genes in heavy metal resistant Streptomyces spec. J. Basic. Microbiol. 40: 295-301.

Ansari M.I., K. Schiwon, A. Malik and E. Grohmann. 2012. Biofilm formation by environmental bacteria, pp. 341-377. In: Malik A and E. Grohmann (eds.). Environmental Protection Strategies for Sustainable Development. Springer.

Booth S.C., M.L. Workentine, J. Wen, R. Shaykhutdinov, H.J. Vogel, H. Ceri, R.J. Turner and A.M. Weljie. 2011 . Differences in metabolism between the biofilm and planktonic response to metal stress. J. Proteome Res. 10: 3190-3199.

Bruins M.R., S. Kapil and F.W. Oehme. 2000. Microbial resistance to metals in the environment. Ecotox. Environ. Safe. 45: 198-207.

Cappuccino J.G. and N. Sherman. 2007. Microbiology: A Laboratory Manual. 7th ed. Pearson Education.

Castonguay M.H., S. Van der Schaaf, W. Koester, J. Krooneman, W. Van der Meer, H. Harmsen and P. Landini. 2006. Biofilm formation by Escherichia coli is stimulated by synergistic interactions and co-adhesion mechanisms with adherence-proficient bacteria. Res. Microbiol. 157: 471-478.
Chen G., G. Zeng, L. Tang, C. Du, X. Jiang, G. Huang, H. Liu and G. Shen. 2008. Cadmium removal from simulated wastewater to biomass byproduct of Lentinus edodes. Bioresource Technol. 99: 7034-7040.

Congeevaram S., S. Dhanarani, J. Park, M. Dexilin and K. Thamaraiselvi. 2007. Biosorption of chromium and nickel by heavy metal resistant fungal and bacterial isolates. J. Hazard Mater. 146: 270-277. De Niederhäusern S., M. Bondi, I. Anacarso, R. Iseppi, C. Sabia, F. Bitonte and P. Messi. 2013. Antibiotics and heavy metals resistance and other biological characters in enterococci isolated from surface water of Monte Cotugno Lake (Italy). J. Environ. Sci. Heal A. 48: 939-946.

Durve A., S. Naphade, M. Bhot, J. Varghese and N. Chandra. 2012. Characterisation of metal and xenobiotic resistance in bacteria isolated from textile effluent. Adv. Appl. Sci. Res. 3: 2801-2806. Duxbury T. 1981. Toxicity of heavy metals to soil bacteria. FEMS Microbiol. Lett. 11:217-220.

Flemming H.C. and J. Wingender. 2010. The biofilm matrix. Nat. Rev. Microbiol. 8: 623-633.

Gadd G.M. 1992. Metals and microorganisms: a problem of definition. FEMS Microbiol. Lett. 100: 197-203.

Harrison J.J., H. Ceri and R.J. Turner. 2007. Multimetal resistance and tolerance in microbial biofilms. Nat. Rev. Microbiol. 5: 928-938. Hausinger R.P. 1987. Nickel utilization by microorganisms. Microbiol. Rev. 51: 22.

Kaluarachchi H., K.C.C. Chung and D.B. Zamble. 2010. Microbial nickel proteins. Nat. Prod. Rep. 27: 681-694.

Karakagh R.M., M. Chorom, H. Motamedi, Y.K. Kalkhajeh and S. Oustan. 2012. Biosorption of Cd and Ni by inactivated bacteria isolated from agricultural soil treated with sewage sludge. Ecohydrol. Hydrobiol. 12: 191-198.

Li Y. and D.B. Zamble. 2010. Nickel homeostasis and nickel regulation: an overview. Chem. Rev. 41: 4617-4643.

Liaqat I., F. Sumbal and A.N. Sabri. 2009. Tetracycline and chloramphenicol efficiency against selected biofilm forming bacteria. Curr. Microbiol. 59: 212-220.

Liesegang H., K. Lemke, R. Siddiqui and H. Schlegel. 1993. Characterization of the inducible nickel and cobalt resistance determinant cnr from pMOL28 of Alcaligenes eutrophus CH34. J. Bacteriol. 175: 767-778.

Macomber L. and R.P. Hausinger. 2011. Mechanisms of nickel toxicity in microorganisms. Metallomics. 3: 1153-1162.

Madhaiyan M., S. Poonguzhali and T. Sa. 2007. Metal tolerating methylotrophic bacteria reduces nickel and cadmium toxicity and promotes plant growth of tomato (Lycopersicon esculentum L.). Chemosphere 69: 220-228.

Markowicz A., T. Płociniczak and Z. Piotrowska-Seget. 2010. Respone of bacteria to heavy metals measured as changes in FAME profiles. Pol. J. Environ. Stud. 19: 957-965.

Mulrooney S.B. and R.P. Hausinger. 2006. Nickel uptake and utilization by microorganisms. FEMS Microbiol. Rev. 27: 239-261.

Nieminen T.M., L. Ukonmaanaho, N. Rausch and W. Shotyk. 2007. Metal ions in life sciences, pp. 1-30. In: Sigel A., R.K.O. Sigel and H. Sigel (eds). Metal Ions in Life Sciences. John Wiley and Sons, West Sussex, UK.

Nies D.H. 1992. Resistance to cadmium, cobalt, zinc, and nickel in microbes. Plasmid. 27: 17-28.

Nies D.H. 1999. Microbial heavy-metal resistance. Appl. Microbiol. and Biotechnol. 51: 730-750.

Nies D.H. 2006. Efflux mediated heavy metal resistance in prokaryotes. FEMS Microbiol. Rev. 27: 313-339.

Özdemir S., E. Kilinc, A. Poli, B. Nicolaus and K. Güven. 2012. $\mathrm{Cd}, \mathrm{Cu}, \mathrm{Ni}, \mathrm{Mn}$ and $\mathrm{Zn}$ resistance and bioaccumulation by thermophilic bacteria, Geobacillus toebii subsp. decanicus and Geobacillus thermoleovorans subsp. stromboliensis. W.J. Microbiol. Biotechnol. 28: 155-163. 
Pal A., P. Choudhuri, S. Dutta, P. Mukherjee and A. Paul. 2004. Isolation and characterization of nickel-resistant microflora from serpentine soils of Andaman. W.J. Microbiol. Biotechnol. 20: 881-886.

Park J.E., K.E. Young, H.G. Schlegel, H.G. Rhie and H.S. Lee. 2003. Conjugative plasmid mediated inducible nickel resistance in Hafnia alvei 5-5. Int. Microbiol. 6: 57-64.

Perrin C., R. Briandet, G. Jubelin, P. Lejeune, M.A. MandrandBerthelot, A. Rodrigue and C. Dorel. 2009. Nickel promotes biofilm formation by Escherichia coli K-12 strains that produce curli. Appl. Environ. Microbiol. 75: 1723-1733.

Qurashi A.W. and A.N. Sabri. 2012. Bacterial Exopolysaccharide and Biofilm Formation stimulate Chickpea growth and Soil Aggregation under Salt Stress. Braz. J. Microbiol. 43: 1183-1191.

Ragsdale S.W. 2009. Nickel-based enzyme systems. J. Biol. Chem. 284: 18571-18575.
Randrianarivelo R., S. Sarter, E. Odoux, P. Brat, M. Lebrun, B. Romestand, C. Menut, H.S. Andrianoelisoa, M. Raherimandimby and P. Danthu. 2009. Composition and antimicrobial activity of essential oils of Cinnamosma fragrans. Food Chem. 114: 680-684.

Roane T. and I. Pepper. 1999. Microbial responses to environmentally toxic cadmium. Microbial. Ecol. 38: 358-364.

Schmidt A., G. Haferburg and E. Kothe. 2007. Superoxide dismutases of heavy metal resistant streptomycetes. J. Basic. Microbiol. 47: 56-62.

Wani P.A. and M.S. Khan. 2013. Nickel Detoxification and Plant Growth Promotion by Multi Metal Resistant Plant Growth Promoting Rhizobium Species RL9. B Environ Contam Tox. DOI 10.1007/ s00128-013-1002-y: 1-8.

Zhu T., J. Tian, S. Zhang, N. Wu and Y. Fan. 2011. Identification of the transcriptional regulator $\mathrm{NcrB}$ in the nickel resistance determinant of Leptospirillum ferriphilum UBK03. PloS one. 6: e17367. 